\title{
DEMOCRATIC EQUALITY AND RESPECT
}

Kenneth Baynes*

\begin{abstract}
RESUMO - O artigo procura mostrar que a idéia liberal de assegurar uma igual liberdade para todos deve ser reexaminada em dois âmbitos de discussões acerca de um desejável equilíbrio entre liberdade e igualdade, de forma a evitar a separação tanto da liberdade e da igualdade como dos domínios opondo reivindicações formais e substantivas. Estas devem antes ser consideradas em suas condições correlatas, exigidas para um exercício democrático efetivo da autonomia privada e pública dos cidadãos, como foi sugerido por Habermas.O artigo mostra que a questão da igualdade de condição não pode evitar as difíceis questões suscitadas pelo chamado debate sobre a "diferença" e tentativas de ir "além da igualdade e da diferença " ou de "reconstruir" um ideal de igual cidadania numa democracia. Deve lidar com aspectos levantados em discussões sobre a igualdade de condição e o respeito.
\end{abstract}

PALAVRAS-CHAVE - Democracia. Habermas. Igualdade. Liberdade. Respeito.

\begin{abstract}
The article seeks to show that the liberal idea of securing an equal liberty for all must be reexamined in the two sets of discussions around the sought-for balance between liberty and equality, so as to avoid the separation both of liberty and equality and of the domains opposing formal and substantive claims. These must be rather regarded in their correlated conditions, required for an effective, democratic exercise of citizens' private and public autonomy, as Habermas suggested. The article shows that the question of equality of condition cannot avoid the difficult questions raised in the so-called "difference" debate and attempts to go "beyond equality and difference" or to "reconstruct" an ideal of equal citizenship in a democracy must address considerations raised in the discussions concerning equality of condition and respect.
\end{abstract}

KEY WORDS - Democracy. Equality. Habermas Liberty. Respect.

Within liberal political theory equality has traditionally taken a back seat to liberty. The idea, roughly, has been that each person should have an equal right to liberty (or a basic set of liberties) and that the aim of securing liberty equally is in turn demanded by a still more basic principle of (equal) respect ${ }^{1}$. Or, to put it even more bluntly, liberalism aims at securing an equal liberty for all. Beginning more or less with Rawls's A Theory of Justice (1971), attempts have been made to realign the balance between liberty and equality, largely through refinements in what a 'substantive' as opposed to merely 'formal' account equality of opportunity requires ${ }^{2}$. More recently still, and now largely in response to Rawls's work, there has been a

* Professor of Philosophy and Political Science, Syracuse University, New York.

1 See, among many possible examples, Robert Nozick, Anarchy, State and Utopia (New York: Basic Books, 1974).

2 For a very insightful discussion of these refinements, see Will Kymlicka, Contemporary Political Philosophy (New York: Oxford University Press, $2^{\text {nd }}$ ed., 2002).

\begin{tabular}{|l|l|l|l|l|r} 
VERITAS & Porto Alegre & v. 53 & n. 1 & março 2008 & p.103-122
\end{tabular}


renewed and more extensive discussion among egalitarians about the appropriate metric of equality or, as it is sometimes put, the appropriate equalisandum. What is it that egalitarians want to make equal - welfare, resources, a set of functionings or basic capabilities, or perhaps some combination of these? Yet, somewhat surprisingly, a principle of individual choice and responsibility (that is, liberty) continues to play a dominant role inside these accounts of equality. Whether it is welfare, resources or something else, the idea has been widely embraced that egalitarians seek to limit inequalities that arise through no fault of the individual but, rather, are the result of "brute luck". On the other hand, inequalities that result from the voluntary choices of individuals (or that can by some other means be traced to what an individual "identifies" with) have been largely seen as unobjectionable or at least less urgent ${ }^{3}$. And, it has been further urged, failure to track individual responsibility in this way constitutes a failure to treat that person with (equal) respect ${ }^{4}$. Thus, somewhat ironically, apparently the conclusion to be drawn from this last set of discussions is that equality is again subservient to liberty: the overarching idea is that an individual is responsible for his freely-chosen fate, while it is only the unequal effects of bad luck that, for the sake of equality, demand compensation.

Along with several other critics of what has been called "luck egalitarianism", I believe it is a mistake to rest the egalitarian project on such a fundamental distinction between choice and circumstance, but the recent discussions have nonetheless importantly pointed to the question of how basic (political) values, including a principle of individual responsibility, fit into a coherent account of what individuals (and, in particular, citizens) owe one another as a matter of (egalitarian) justice ${ }^{5}$. In the first section of my presentation, I offer an overview of the recent 'equality of condition' or 'luck egalitarian' debate. One aim of this overview is to suggest that considerations of 'equality of condition' invariably lead into debates about political equality and, in particular, the right of citizens to an equal opportunity to influence outcomes ${ }^{6}$. This is not only because political equality (or the equal opportunity for political influence) helps in part to secure the other basic capabilities required for treating a person with respect, but also - and perhaps more importantly - because political equality emerges as a fundamental and extremely demanding value in its own right. On the one hand, in modern societies characterized by "reasonable pluralism" securing political equality is more demanding than often assumed:

3 More recently, G. A. Cohen has modified his position on this distinction between choice and circumstance, suggesting that, even if the set of preferences responsible for the inequalities are chosen, compensation may be required so long as it's expensive character is itself unchosen; see "Expensive Tastes Rides Again", in Dworkin and His Critics, ed. by Justine Burley (New York: Blackwell, 2004), pp. 1-29.

4 See G. A. Cohen, "On the Currency of Egalitarian Justice", Ethics 99 (1989), p. 914; John Roemer, Equality of Opportunity (HUP, 1998), and Jonathan Wolff, "Fairness, Respect, and the Egalitarian Ethos", Philosophy and Public Affairs 27 (1998).

5 Elizabeth Anderson, "What is the Point of Equality?" Ethics 109 (1999), 287-337 and Samuel Scheffler, "What is Egalitarianism?," Philosophy and Public Affairs 31 (2003), 1-39.

6 For a related argument that the 'equality of what' literature ignores the importance of political equality, see Harry Brighouse, "Egalitarianism and the Equal Availability of Political Influence", The Journal of Political Philosophy 4 (1996), pp. 118-142. 
the equal opportunity (or equal availability) of political influence imposes egalitarian demands that go well beyond more familiar political rights and liberties even if the more specific content of those demands can only be settled once political equality is secure. And, on the other hand, political equality among citizens is required if there is to be a public means for determining and prioritizing further basic interests (and the conditions required for their effective realization). In both cases, then, or so I shall argue, equality is not simply the handmaiden of liberty; rather equality (including especially political equality) are interdependent in more complex ways than the 'equality of condition' debate suggests. Egalitarians on this view should aim not at equalizing the effects of brute luck in order to make room for individual responsibility. Rather, they should be committed to a 'society of equals' (Scheffler) in which citizens viewed as free and equal can collectively govern their common fate. On this view, it makes no more sense to claim that equality is in the service of liberty than it does to claim the reverse. Or perhaps better expressed: a society of equals and a scheme of (equal) liberties reciprocally define one another and political equality in particular again emerges as a central political and (public) moral value. In the second section of my paper I try to support this claim with a brief review of the 'equality and difference' debate. Further, this discussion shows that treating a person with respect is more demanding than generally assumed: it requires not only respect for certain general features or capacities that we all share in common but also, in ways that it is difficult to determine in advance, respect for what, as a source of value for her, makes a person unique or distinct. Yet, this latter form of respect - respect for distinctness - does not derive directly from the agent's values (or preferences) per se but from the reasons she is able to offer in their support ${ }^{7}$. Respect thus demands modes of 'democratic iteration' (Benhabib) as a form of public or collective reasoning and so, again, places a high priority on political equality. Finally, in the third and last section of my presentation, I will argue that, despite the importance of equality, it is a value that is often best secured indirectly - that is, not by attempts to measure whether any given person's overall standing is the result of choice or circumstance but rather by attempts to secure it through the arrangement of the 'basic structure' of society ${ }^{8}$.

Critics of liberal equality have traditionally argued (somewhat paradoxically) either that the idea of equality is empty and has no independent value apart from its connection to other ideals or that its unchecked pursuit conflicts with other political

This point, at the core of most deliberative democratic theory, has recently been ably defended by Anthony Simon Laden, Reasonably Radical: Deliberative Liberalism and the Politics of Identity (Ithaca: Cornell University Press, 2001).

8 In "Defending Equality of Outcome" [The Journal of Political Philosophy 12 (2004), pp. 1-19] Anne Phillips argues persuasively that current interpretations of equality of opportunity lead to an ultimately incoherent (and hence unworkable) distinction between choice and circumstance. However, I believe that her own return to 'equality of outcome', while important in some respects, also neglects the fundamental importance of political equality that she herself stresses in other work (see especially her, Which Equalities Matter? (Cambridge: Polity Press, 1999), esp. chapter 2. 
values, such as liberty ${ }^{9}$. Thus, for example, Harry Frankfurt has recently reiterated his earlier claim that "egalitarianism is not an ideal of any intrinsic moral importance" (146) and proposes the ideal of sufficiency as an alternative, while John Kekes, in his recent book, The Illusions of Egalitarianism, writes that "equal human worth is an illusion. The truth is that there are good reasons to believe in moral inequality and there are safeguards that can prevent its abuse" (98). Though the criticisms look similar on the surface, for Frankfurt, equality is an empty ideal, whereas for Kekes it is a substantive one genuinely opposed to others. Clearly, moral inequality could not constitute a genuine alternative if moral equality were merely empty and, for the most part, critics limit their opposition to aspirations for more than formal equality since it will conflict with other important values, most notably liberty. Finally, these generally more conservative critics of equality have recently been joined by some feminists and by others working on the politics of identity or recognition. Liberal equality, according to these theorists, offers a formal and abstract ideal that in practice perpetuates inequalities by privileging those who conform to the underlying (and for the most part unspoken) norms in light of which judgments of equality and difference are made ${ }^{10}$. According to both sets of criticisms, liberal equality holds out a vision of society in which differences are illegitimately excluded and in which everyone is compelled to be the same.

I don't maintain that these criticisms cannot find any foothold within liberal theory - liberalism is, after all, a large and diverse tradition. I do want to claim, however, that they don't apply to the best arguments for liberal equality. In particular, I shall argue that in recent discussions of "liberal egalitarianism" the relationship between liberty and equality has been a central concern and this relationship has been explored in some instructive ways ${ }^{11}$. Liberal equality, these discussions show, is neither an empty ideal nor in an irresolvable and deep conflict with other values. On the other hand, the reservations voiced by some feminist and multicultural critics suggest that the attempts to specify an adequate conception of equality have not yet been successful. In particular, they suggest that its connections with the ideas of autonomy, choice and power must be explored further.

My own survey of the literature has uncovered two somewhat distinct fields of discussion. On the one hand, guided by the question 'equality of what?', there is a body of literature that has sought to identify a general measure or metric of equality that could be used to compare the life prospects of otherwise diverse individuals and groups. This literature is primarily concerned with what can be called "equality

9 Peter Westen, "The Empty Ideal of Equality", Harvard Law Review 95 (1982); W. Letwin, ed., Against Equality (London: Macmillan, 1983); and J. Lucas, "Against Equality", Philosophy 40 (1965).

10 For some examples of this literature, see Iris Young, Justice and the Politics of Difference (Princeton University Press, 1990); Zillah Eisenstein, The Female Body and the Law (Berkeley: University of California, 1988); Charles Taylor, Multiculturalism and the 'Politics of Recognition' (Princeton University Press, 1992); and Wendy Brown, States of Injury (Princeton University Press).

11 For a good earlier discussion of the "internal connection" between equality and liberty, see S. Lukes, "Equality and Liberty: Must They Conflict?" in Moral Conflict and Politics (New York: Clarendon Press, 1991), pp. 50-70. 
of condition" or "equality of life prospects" ${ }^{12}$. On the other hand, there is a body of literature centered on questions of equal citizenship, democratic equality or 'participatory parity' (Fraser) ${ }^{13}$. Here focus is on the attempt to give substantive content to the formal principle of equality - treat equals equally - within a variety of different contexts: for example, what is required for legal, political, economic, sexual, or racial and ethnic equality, and what is the best arrangement of these equalities among themselves and with other values. In each of these contexts, the formal imperative to treat equals equally requires interpretation about who is to be considered an equal and what it means to treat them equally. Iris Young captures this second set of concerns nicely when she writes: "Equality refers not primarily to the distribution of social goods, though distributions are certainly entailed by social equality. It refers primarily to the full participation and inclusion of everyone in a society's major institutions, and the socially supported substantive opportunity for all to develop and exercise their capacities and realize their choices" ${ }^{14}$. In the context of discussions on multiculturalism and sex and gender equality, this principle of equal citizenship has sometimes led to the call for special group rights ${ }^{15}$.

What I shall claim is that these two sets of discussions are not as widely separate as might initially be supposed. Rather, attempts to address the question of equality of condition cannot avoid the difficult questions raised in the so-called "difference" debate; and, on the other hand, attempts to go "beyond equality and difference" or to "reconstruct" an ideal of equal citizenship must address considerations raised in the discussions concerning equality of condition. On its best interpretation, I shall argue, liberal equality refers to the equal access of all individuals to the conditions required for self-realization and self-determination, or, to borrow Habermas's recent formulation, to the conditions required for an effective exercise of citizens' private and public autonomy ${ }^{16}$. The presence in a society of any disadvantage in access to such conditions that is not attributable to the genuine choices of the individual makes the society to that extent less egalitarian. On this view, egalitarians are committed to providing equal access to the social conditions of freedom. However, in contrast to the prevailing view within the 'equality of condition' literature, the fact that a person's unequal access may be the result of his choice, does not mean that others

12 I borrow this term from the helpful survey of equality offered by Richard Arneson, "Equality" in $A$ Companion to Political Theory, ed. by R. Goodin (Blackwell, 1993), pp. 489-507.

13 For a useful discussion of this "principle of equal citizenship" within the context of U. S. Constitutional theory, see Kenneth Karst, "Why Equality Matters", Georgia Law Review 17 (1983): 245-289; on 'democractic equality', see Elizabeth Anderson, "What's the Point of Equality?"; and on 'participatory parity', see Nancy Fraser and Axel Honneth, Redistribution or Recognition? (New York: Verso, 2003), p. 36.

14 Justice and the Politics of Difference, p. 173.

15 In addition to the works cited above by Iris Young and Charles Taylor, see Will Kymlicka, Liberalism, Community and Culture (Oxford: Clarendon Press, 1989).

16 See Jürgen Habermas, Between Facts and Norms (Cambridge: MIT Press, 1996), chap. 3 and my discussion of public and private autonomy in "Democracy and the Rechtsstaat" in The Cambridge Companion to Habermas, ed. by S. White (New York: Cambridge University Press, 1995). Interestingly, in his "Reply to Habermas" Rawls also describes his model of "justice as fairness" as an attempt to secure citizen's public and private autonomy (in Political Liberalism). 
owe him nothing as a matter of (egalitarian) justice and, as importantly, given the complex interconnections between choice and circumstance, it is often both impractical and undesirable to attempt to track in particular cases the sources of a person's condition ${ }^{17}$. Rather, as I argue in the final section of this paper, liberal egalitarians should instead focus on the background institutions that shape the choices individuals make and, most importantly, on the equal availability of access to the "second-order" institutions established to monitor and regulate those background institutions.

Finally let me mention one further caveat at the outset: The approach to equality defended here gives rise to an unavoidable circularity. The attempt to specify in any detail what constitutes "equal access to advantage" (Cohen) or to define the necessary social conditions for equal citizenship cannot avoid making assumptions that could in turn only be confirmed if those assumptions were first realized in actu. The relevant tensions and appropriate trade-offs between equality and liberty, or between the 'liberties of the ancients' and the 'liberties of the moderns', cannot be identified apart from the creation of institutions of opinion- and will-formation that assume such identifications have already been made. I see no way to escape this difficulty; however, rather than viewing it as a defeat, I think it points to the fluid and dynamic relation between liberty and equality within a broader commitment to democracy. My only other consolation is that I do not see how those who criticize this position can avoid a similar circularity of their own, unless they more or less arbitrarily suspend their own argument.

\section{I. 'Equality of What?': From Rawls to Cohen and beyond}

Recent discussions of equality of condition or equality of life prospects are greatly indebted to Rawls's critique of utilitarian and, more generally, welfarist conceptions of equality. Equality of welfare is committed to promoting the most equitable distribution of utility or preference satisfaction compatible with other values. However, this position is subject to what has been called the "expensive tastes" objection $^{18}$. If Bill has preferences that are much more costly to satisfy than the preferences of Sam, then it seems equality of welfare requires distributing more resources to bring Bill up to the same level of welfare as Sam. As Rawls points out, however, this approach ignores the extent to which individuals can be held responsible for the preferences they have. What a truly egalitarian metric ought to take into consideration is not all preferences and desires, but those which are not due to genuine choices of the individual or with which he does not otherwise identify. To borrow Ronald Dworkin's terminology, we need a distinction between "brute luck" and "option luck" and it is only inequalities resulting from the former that should

17 See Anne Phillips, "'Really' Equal: Opportunities and Autonomy", The Journal of Political Philosophy 14.1 (2006), pp. 18-32 and Elizabeth Anderson, "What is the Point of Equality?"

18 John Rawls, "Social Unity and Primary Goods", in Utilitarianism and Beyond, ed. by A. Sen and B. Williams (New York: Cambridge University Press, 1982), p. 168-69, and G. Cohen, "On the Currency of Egalitarian Justice", Ethics 99 (1989), p. 913f. 
command the attention of egalitarians ${ }^{19}$. Society, on this view, has little (if any) obligation to redistribute in the direction of greater equality if the inequalities are the result of genuine choices individuals have made.

However, as critics have noted, Rawls's introduction of an account of primary goods and other resourcist accounts of the appropriate metric of equality - such as Dworkin's - do not necessarily follow from this critique of welfarism and they run into difficulties of their own ${ }^{20}$. One of the better-known criticisms has been offered by Amartya Sen: Although he agrees with this critique of welfare metrics, Sen argues that the resource or goods approach is "fetishistic" ${ }^{21}$. Resourcists like Rawls and Dworkin focus on what it is that individuals have, rather than on what they are able to do or be with what they have. This has led Sen to propose what he calls a capabilities or functionings account of the egalitarian metric. The aim then is to identify a range of human functionings or capabilities relative to a (now culturally defined) notion of well-being. Such functionings range from "elementary" ones such as escaping morbidity and mortality, being adequately nourished, and having mobility to "higher" or more complex ones such as being happy, achieving selfrespect, taking part in the life of the community, and appearing in public without shame $^{22}$. A society is more egalitarian to the extent it provides equally an effective opportunity for each citizen to develop and exercise the relevant range of human capabilities $^{23}$.

Finally, in what can be called a third round in the discussion, critics such as Richard Arneson and Gerald Cohen have pointed to difficulties in this capabilities approach. In particular, there is a problem of indexing, since individuals have a diversity of capabilities and since any two individuals may have very different sets. Thus, if one attends to capabilities rather than utility or primary goods, there seems to be no common measure in terms of which judgments of equality can be made. According to Arneson, this implies that Sen's capabilities approach must either adopt an objective or perfectionist account (which he considers unacceptable in liberal democratic society) or it collapses into a modified form of welfarism - what Arneson calls equality of opportunity for welfare ${ }^{24}$. Cohen, by contrast, claims that Arneson's retreat to welfarism is overly hasty and introduces a notion of "midfare" as an alternative to Sen's notion of capabilities ${ }^{25}$. Midfare refers to a heterogenous set of goods - something between utility and goods - that comprise the conditions for well-being - not utility since it is not simply a matter of an individual's mental state

19 Ronald Dworkin, "What is Equality?", Philosophy and Public Affairs 10 (1981), and Cohen, "On The Currency of Egalitarian Justice", p. 931.

20 Gerald Cohen, "Equality of What? On Welfare, Goods, and Capabilities" in The Quality of Life, ed. by M. Nussbaum and A. Sen (New York: Oxford University Press, 1993), p. 13.

21 "Equality of What?" in Liberty, Equality, and Law: Selected Tanner Lectures on Moral Philosophy, ed. by S. McMurrin (Salt Lake City: University of Utah Press, 1987), p. 158.

22 "Capability and Well-Being" in The Quality of Life, p. 37.

23 Sen, "Equality of What?" and Inequality Reexamined (New York: Clarendon, 1992).

24 Arneson, "Equality", p. 25.

25 Cohen, "Equality of What?", p. 27. 
or desires, but not goods since the concern is with what goods do for the individual. Further, he claims that, while it may be difficult to develop a complete or full metric, it is nonetheless possible and worthwhile to develop a list of basic midfare, corresponding to a "normal human existence". These would include such fundamental goods as health, nutrition, and housing. Only when it is a matter of the "higher" or more complex capabilities do issues of pluralism complicate his own model ${ }^{26}$. Nonetheless, according to Cohen, his focus on midfare remains true to at least one central egalitarian concern that no one should be lacking in an "urgent desideratum" through no fault of their own.

However, while clearly preferable to some of the available alternatives, Cohen's proposal, which he calls "equality of access to advantage," is still inadequate as an egalitarian metric. First, despite its attention to fundamental capabilities, it remains captive to what Iris Young has called the "distributive paradigm" in theories of justice ${ }^{27}$. His notion of midfare focuses on basic capabilities - health, nutrition, and housing - to the neglect of "higher" capabilities that, at least in many current social movements, are the focus of attention. In this respect it even falls behind Rawls's concern to secure an equal and effective exercise of the two moral powers - namely, the capacity to form and pursue a conception of the good and the capacity to have a sense of justice. If, following Iris Young, the capabilities whose equal and effective opportunity for development society ought to insure is broadened to include selfrealization and self-determination, the resources required would have to be modified. In particular, they would have to include greater access to decision-making structures and processes, a more extensive reconfiguration of the social division of labor, and greater participation in the production and interpretation of cultural meanings. In short, as it presently stands, Cohen's model would seem to have the least to offer on just those questions that many contemporary social movements regard as most important.

In a second, more fundamental criticism of this 'equality of condition' literature, Elizabeth Anderson argues that these theorists have lost sight of the proper aim or point of equality. According to Anderson, this literature has, for a variety of reasons, become focused on compensating people for undeserved bad luck - "being born with poor native endowments, bad parents, and disagreeable personalities, suffering from accidents and illness, and so forth" (288). By contrast, she continues, "the proper negative aim of egalitarian justice is not to eliminate the impact of brute luck from human affairs, but to end oppression, which by definition is socially imposed. Its proper positive aim is not to ensure that everyone gets what they morally deserve, but to create a community in which people stand in relations of equality to others" (288-9). She describes this alternative as "democratic equality" and states that its aim is to "guarantee all law-abiding citizens effective access to the social conditions of their freedom at all times" (289). The former model, which she dubs 'luck egalitarianism', loses sight of the relational dimension of freedom and, as a result,

26 Cohen, p. 27.

27 Justice and the Politics of Difference, chapter 1. 
becomes too exclusively focused on whether a person's condition is due to circumstances over which she has no control or to choices for which she must bear responsibility, wherever the chips might fall. But this account seems to misconstrue the connection between liberty and equality: egalitarians should not employ a distinction between choice and unchosen circumstance in order to compensate for the latter, while leaving the outcomes resulting from choice wherever they fall. This view, as Anderson points out, suggests that the motorcyclist who voluntarily declines health insurance is not, as a matter of equality, owed anything if he has a serious accident. It also suggests that whatever the disadvantage, if it is due to brute luck rather than choice, the individual is entitled to compensation as a matter of equality. Yet, Anderson continues, do we really owe compensation for an expensive taste say, an intense desire for an exotic vacation - simply because the desire is not chosen? Finally, the goal of distributing on the basis of what is due to choice and what is a matter of unchosen circumstance leads to extensive invasions by the state into the private liberties of citizens, as well as potentially humiliating judgments regarding the causes of an individual's condition. In short, despite the appeal of guaranteeing equal access to advantage, something seems to have gone wrong with this particular construal of the relation between freedom and equality.

Anderson's alternative account, as I just noted, has a different aim: to remove social oppression and to secure "the social conditions for everyone's freedom". Her account also rejects both welfare and resources as the appropriate egalitarian metric and, like Cohen's, also draws upon Sen's capabilities approach. More specifically, Anderson identifies three broad sets of capabilities (or sets of functionings) that should be of paramount concern to egalitarians: the ability to function "as a human being, as a participant in a system of cooperative production and as a citizen of a democratic state" (317). In connection with each of these general capabilities, she proposes a more specific set of functionings. For example, to effectively function as a citizen "requires rights to political participation, such as freedom of speech and the franchise, and also effective access to the goods and relationships of civil society. This entails freedom of association, access to public spaces such as roads, parks, and public transportation, the postal service, and telecommunications. This also entails the social conditions of being accepted by others, such as the ability to appear in public without shame, and not being ascribed outcast status" (318). Anderson also offers corresponding lists for the other two general capabilities. The specific details of her proposal are not important at the moment, but I offer some general remarks in connection with the thesis I wish to defend here: First, Anderson's account links freedom and equality in a way quite different than Cohens's. Equality aims at a like liberty for all and, conversely, individual liberties are ordered in connection with the goal of a (free) society of equals. Thus, liberty and equality play a role in the interpretation and defense of the other and this reciprocal relation becomes more important as the specific details of each are contested. Second, not only do the three general capabilities she mentions - functioning as a human, as an economic agent, and as a citizen - lead rather quickly to socially and culturally 
specific features, my own suspicion is that the ability to function as a citizen must itself be both a condition for determining the more specific capabilities for being a human and an economic agent and a capability that cannot be achieved without first securing to some significant degree the other two capabilities. So, for example, we cannot know what impedes "the ability to appear in public without shame" unless we know what features of a person's identity are considered centrally important to him or her and yet we cannot know what features of a person's identity are considered centrally important unless that person has an adequate and effective opportunity to articulate them in a public forum without shame. So, to repeat my own initial thesis, not only are liberty and equality 'co-original', political equality in particular ('functioning as a citizen') presupposes the other capabilities for its effective exercise yet is also required for determining their more specific functionings in particular social and cultural contexts.

\section{Equal Citizenship and the Dilemma of Difference}

Once this predominantly theoretical question of finding an equality metric is posed in terms of the question of determining what counts as a "normal human existence", it seems clear that no sharp distinction between this question and the question of equality of citizenship can be maintained. The question of what counts as "normal human existence" or what are the fundamental capabilities and capacities that should be socially supported on the basis of considerations of equality are themselves contestable matters - especially if one does not restrict oneself to a minimal set of basic needs.

It is at this point, I think, that some of the recent literature on equality and difference, particularly what has emerged from the context of feminist legal theory, is relevant. A central criticism made by many of these theorists is that the formal principle of equality - and especially notions of legal equality - always operates against a prior and more substantive norm with reference to which judgments of equality and difference are made. This norm, however, quite frequently reflects features of a particular dominant group - generally, white, heterosexual men - and treats these as "normal". Examples of this abound - in legal decisions concerning sexual harassment and rape, in laws regulating working hours and other conditions of employment, in policies related to pregnancy and maternity leaves, and many other areas of legal decision. Legal equality is formal equality and, since it operates against inegalitarian background norms, it frequently serves an ideological function.

Moreover, attempts to secure sex equality in law have thus far generally pursued either an "assimilationist model" (which emphasizes the extent to which we are all alike) or an "accommodation model" (which seeks to create "special rights" on the basis of "real" differences). As some feminists point out, however, both models founder upon the same problem. In attempting to determine which differences deserve legal remedies and which should be ignored the background norms which establish terms of relevance and in light of which judgments of similarity and 
difference are made frequently go unchallenged ${ }^{28}$. Martha Minow points to a difficulty in both strategies in illustrating what she calls "the dilemma of difference":

By taking another person's difference into account in awarding goods or distributing burdens, you risk reiterating the significance of that difference and, potentially, its stigma and stereotyping consequences. But if you do not take another person's difference into account - in a world that has made that difference matter - you may also recreate and reestablish both the difference and its negative implications. If you draft or enforce laws you may worry that the effects of the laws will not be neutral whether you take difference into account or you ignore it ${ }^{29}$.

One alternative model of equality, proposed by Christine Littleton, seeks to avoid this dilemma ${ }^{30}$. In rejecting both assimilationist and accomodationist models it neither denies difference nor accepts recognized differences as deviations from a norm requiring "special treatment". Rather, on this model of "equality as acceptance" the aim of legislation and judicial interpretation should be to "make difference costless" by removing the various types of "cost" that attach to sex and gender differences. For example, Littleton calls for establishing "gendered complements" so that different forms of traditionally "women's work" such as care-giving can be compensated in ways comparable to the equivalent work of men. More importantly, however, the model of "equality as acceptance" also requires critically questioning and examining the "cultural meanings" that inform the way such valuations are made. The underlying norms and valuations that inform judgments of "gendered complements" must, it would seem, be seen as "social constructs" that are open to revision in light of contested need interpretations.

Despite the advantages of this approach - especially as a legal remedy for dealing with enduring forms of sexual inequality - objections have been raised against it as well. In particular, some feminists worry that the legal recognition of culturally defined differences will only contribute to their perpetuation - the view that women as socially and culturally constructed really are better at some kinds of activities than others. For example, the notion of "gendered complements" in the work force might tend to perpetuate a kind of "mommy track" in which caregivers or dependency workers, despite receiving higher salaries, would nonetheless continue to be mostly women ${ }^{31}$. On this model, there seems to be little incentive to redefine or even abolish gender-identities and little incentive to alter the sexual division of labor. In a similar vein, Catharine MacKinnon warns that over-attention

28 See Christine Littleton, "Reconstructing Sexual Equality" in Feminist Jurisprudence, ed. by Patricia Smith (Oxford, 1992), pp. 110-135; Deborah Rhode, Justice and Gender (Harvard University Press, 1989); Catharine MacKinnon, "Difference and Dominance: On Sex Discrimination" in Feminism Unmodified (Cambridge: Harvard University Press, 1987), pp. 32-45.

29 Martha Minow, "Justice Engendered", in Feminist Jurisprudence, p. 232.

30 "Reconstructing Sexual Equality", in Feminist Jurisprudence; the same approach has also been defended by Deborah Rhode in "The Politics of Paradigms: Gender Difference and Gender Disadvantage" in Beyond Equality and Difference, ed. by G. Bock and S. James (New York: Routledge, 1992), pp. 149-163.

31 Nancy Fraser, "After the Family Wage: What Do Women Want in Social Welfare?" in Justice Interruptus (New York: Routledge, 1997). 
to questions of difference can obscure questions of unequal power which should be the real concern in sex equality law ${ }^{32}$.

What seems clear from these reservations about the model of "equality as acceptance" is that at a minimum any measures taken to make difference costless must also critically scrutinize the origin of those differences and, more importantly, the multiple functions they may be serving in the prevailing social arrangement of power and opportunities. Furthermore, such a critical scrutinizing would itself seem to presuppose a genuinely pluralist or heterogenous public sphere in which background norms and need interpretations can be contested.

In Justice and the Politics of Difference Iris Young develops Littleton's conception of equality as acceptance in connection with her own idea of a "heterogeneous public." Rather than an ideal of the universal citizen that transcends difference and requires that each citizen be treated the same, she argues for a positive affirmation and proliferation of group differences as the best means for achieving equality. "In this vision the good society does not eliminate or transcend group difference. Rather, there is equality among socially and culturally differentiated groups, who mutually respect one another and affirm one another in their differences" ${ }^{33}$. On this view, "social justice... requires not the melting away of differences, but institutions that promote reproduction of and respect for group differences without oppression" ${ }^{34}$.

According to Young, this "politics of difference" will require specific measures to guarantee the representation of oppressed or disadvantaged groups within the political process. She proposes, among other things, public funding to enable group organization and policy-formation, mechanisms to insure that the appropriate decision-makers have considered proposals offered by disadvantaged groups, and even group veto power regarding specific policies that affect a group directly ${ }^{35}$. As examples of this last proposal she suggests veto rights for women in relation to reproductive rights policy and veto rights for Native Americans over the use of reservation lands.

I will set aside here any assessment of her specific policy recommendations which, as she acknowledges, must be designed with a view toward a variety of considerations, including general equal opportunity rights. Rather, what I want to point out is Young's general proposal that equality requires not "difference-blind" policies, but policies that self-consciously recognize group differences. In this respect her proposal is similar to that offered by Charles Taylor in the context of debates about multicultural rights. In both cases, equality requires attending not only to the ways in which individuals are the same, but also to the ways in which individuals are different or unique ${ }^{36}$. Or, perhaps better stated, the principle of equal consideration gives rise to two distinction notions of respect: respect for a person in

32 Catharine MacKinnon, "Difference and Dominance" in Feminism Unmodified.

33 Justice and the Politics of Difference, p. 163.

34 Ibid., p. 47.

35 Ibid., p. 184.

36 Multiculturalism and the 'Politics of Recognition', p. 38. 
virtue of what she shares in common with other human beings and respect of individual or group uniqueness and distinctness. Sometimes these two forms of respect can be mutual reinforcing; more often, it seems, they come into conflict with one another. At its most powerful and effective, however, claims for recognition based on the idea of respect for individual distinctness or uniqueness can enable a community to see the ways in which existing norms and practices have worked to exclude others from equal access to advantage or undermine participatory parity. For example, this is one way to see what is going on in current debates over same sex marriage. When conflicts around these two forms of respect go well, they often give rise to an articulation of more abstract forms of the first sort of respect. But there is no way to avoid altogether difficult conflicts, nor is it likely that these conflicts can ever be brought to a definitive conclusion. Rather, they are expressions of what Seyla Benhabib has recently called 'democratic iterations', whereby the recognitional demands of the generalized and the concrete other are continuously contested and re-negotiated ${ }^{37}$.

Does this call for a heterogenous public and special rights to group representation require a radical break with the idea of liberal equality as some have suggested or is it, as Will Kymlicka suggests, simply "an old idea with a new twist?" ${ }^{38}$ It would, I think, be a significant break if it were a call for the representation of disadvantaged groups in order to secure their parity and ongoing survival. This in fact seems to be Taylor's position in his remark that cultures can validly claim a right to survive "through indefinite future generations" ${ }^{39}$. Young, however, is more ambiguous: At times she does speak of the need to achieve "equality between groups" but in other formulations she states that justice is concerned with "the institutional conditions necessary for the development and exercise of individual capacities and collective communication and cooperation" ${ }^{40}$. This would locate her position more squarely within a liberal egalitarian conception that need not be hostile to limited forms of group representation - not to insure the indefinite continuation of distinct groups, but to provide individuals with the social conditions for their freedom or to achieve equal standing as citizens.

This reference to the "social conditions of freedom" brings us back to our earlier discussion of "equality of condition". The concern there, as we saw, was that individuals not be disadvantaged, through no fault of their own, in the realization of a relevantly defined set of capabilities. What the literature on "difference" brings to this discussion, I believe, is a radical questioning of the ways in which the relevant set of capabilities are defined. Effective opportunities are diminished not only when individuals are denied access to specific cultural and material resources, but also when those opportunities are constrained by cultural norms and standards that the

37 Seyla Benhabib, "Another Universalism: On the Unity and Diversity of Human Rights", Proceedings of the American Philosophical Association 81.2 (2007), p. 21.

38 Will Kymlicka, "Three Forms of Group-Differentiated Citizenship Rights in Canada", in Politics in the Vernacular (New York: Oxford University Press, 2001).

39 Multiculturalism and the Politics of Recognition, p. 41n.16.

40 Compare her remarks on p. 163 and p. 39. 
individuals in question could not reasonably have played a role in defining. On this view, the effective opportunities of some can undermine the choices of others if the values arising from the former become the basis for defining the norms or standards that are used to judge the equal condition of others. Equal access to advantage then requires that all the individuals in question have an equal opportunity to define the norms or standards in light of which judgments of equality are to be made, and it means that the norms or standards informing the genuine choices of some should not become the basis for defining what counts as the genuine choice of others. To mention one obvious but hardly trivial example, as has often been observed, it is difficult not to believe that legal cases concerning pregnancy leave would have been treated differently if more of the Supreme Court justices involved in the decisions could have become pregnant.

In sum, what the "equality and difference" debate reveals is that any scheme of basic rights and liberties will always be interpreted against a background of sociocultural norms and expectations. Thus, unless there are adequate means for challenging and contesting those background norms, the value of that scheme may be very unequal. As we also saw in the 'equality of condition' literature, this means that political equality - defined as an equal opportunity for political influence, including the introduction of themes and topics, access to deliberative forums, and influence on final decisionmaking - is an important right on its own (e.g., as an expression of respect) and also important as a means for interpreting and securing other basic rights and liberties.

\section{The 'basic structure' as the focus of egalitarian concern}

In the final section of my presentation I will argue that, although securing equal access to the social conditions of freedom is the proper aim of egalitarianism, it is often best pursued indirectly. By 'indirectly' I mean through the institutional design of the 'basic structure' of society (Rawls), rather than through more direct attempts to assess whether, for any given individual or group, his or her condition is due to choice or circumstance ${ }^{41}$. I will argue for this by looking at two cases: (a) first, a brief glance at debates about political equality, and (b) then a slightly longer look at a debate about how social equality more broadly might best be pursued.

(a) There is a tradition that extends back to at least Rousseau's remark that social inequalities should not be so great that they affect a citizen's equal political standing. It is based on the assumption that political influence is both a position good - that is, some cannot have more influence without others having less - and yet an extremely valuable good for citizens. So important, in fact, that the equal opportunity for political influence imposes a significant constrain on the acceptable level of other inequalities. Rawls voices this conviction when he argues that the 'fair value' of the political liberties has a lexical priority over any inequalities that

41 For criticisms of this more 'direct' approach, especially in the work of John Roemer, see Anne Phillips, "'Really' Equal: Opportunities and Autonomy", The Journal of Political Philosophy 14 (2006), pp. 18-32; see also Anderson, "What is the Point of Equality?" 
might be allowed by his difference principle. Few have recognized the radical character of this constraint ${ }^{42}$. It means that, even if greater social inequalities with respect to other goods might improve the worst off's overall condition (by providing, for example, greater material resources) such inequalities would not be permitted. A citizen's equal political standing is thus a strong substantive constraint on other acceptable inequalities.

However, the radical character of this proposal is greatly tempered by the fact that the equal opportunity for political influence is extremely difficult to measure and regulate. I suspect that few people would deny that an individual's rhetorical or persuasive skills are very unequal, yet there are no serious proposals to limit this influence in the political process (such as, transferring all political speech to computer-modulated forms, so that all voices sounded the same!). Although, I note in passing, some have questioned whether an egalitarian can consistently read to his or her child at night, knowing that this is likely to produce differential effects in terms of political influence (J. Swift) and it is not entirely implausible to maintain that political equality requires leveling down the unequal educational opportunities of others. So, how should the equal opportunity to influence political outcomes be measured and/or secured? James Bohman, also drawing on the work of Sen, has argued that "the ability to initiate acts of deliberation" may provide a suitable criterion and he has proposed an account of 'political poverty' as a minimum threshold below which no citizen should fall: "deliberative democracy must fulfill demands for equality in the means for effective participation at least enough so that no citizen is so poor as to fail to influence outcomes or to avoid exclusion" ${ }^{43}$. Yet, as even this shift from a more ambitious egalitarian metric to a sufficiency criterion reveals, the measure of (effective opportunity for) political influence presents a formidable challenge. Further when we begin to consider the range of social goods whose unequal distribution might impact upon a person's effective opportunity for political influence, the challenges for realizing this equality become even greater. For this reason, I think it is important for egalitarians to focus on the broad set of background institutions that shape the contexts of public debate and decisionmaking. This will include not only the protection of basic political rights and liberties, but also serious attempts to restrict the influence of money on the political process and other measures likely to promote and equal access to the resources of public debate and decisionmaking ${ }^{44}$. Public education and public financing of diverse forums for opinion-formation are obviously important here and so too are arguments in favor of new modes of political representation or even special group rights.

My primary concern at this point, however, lies not in the merits of specific proposals. Rather, the general point I want to make with the case of political equality is the following: even if we regard political equality as a centrally important focus

42 See Harry Brighouse, "Political Equality in Justice as Fairness", Philosophical Studies 86 (1997), pp. 155184, and Kenneth Baynes, The Normative Grounds of Social Criticism (NY: SUNY Press, 1992), chap 2.

43 James Bohman, Public Deliberation (Cambridge: MIT Press, 1996), p. 126.

44 Henry Richardson, Democratic Autonomy (New York: Oxford University Press, 2002), p. 89. 
of egalitarian concern, determining in any precise way whether a given individual has unequal political influence will be extremely difficult and may compromise other important political values. This suggests that we should look first to general background measures, rather than more direct attempts to measure equal opportunity for political influence by tracking the origins of any given individual's amount of political influence.

(b) The importance of focusing on the background institutions becomes even clearer when we turn from the case of political equality to the more general question of the social conditions of freedom or what Cohen calls "equal access to advantage". Here I think there are even more compelling reasons to focus on what Rawls calls the 'basic structure' of society. I would like to defend this claim in connection with a recent debate between Cohen and Rawls.

In his book, If You're an Egalitarian, How Come You're so Rich?, G. A. Cohen argues that liberal egalitarians such as Rawls have focused their attention too exclusively on the institutions of a just society and are too little concerned with the choices and motivations of individuals within those institutions. More specifically, Cohen argues that Rawls's second principle of justice - the difference principle - at least on its more common or standard interpretation, condones economic inequalities that arise solely from the selfish unwillingness of the talented to work for less. If, by contrast, an ethos of fraternity or solidarity were more widespread in society, the incentives sanctioned by the difference principle would not be necessary and the situation of the worst-off could be improved without the same degree of inequality. Cohen's claim then is that Rawls's primary concern with institutions - especially as the primary means for implementing the difference principle - takes for granted and leaves untouched the selfish interests of maximizers in the market. As a result, Cohen argues, Rawls leaves intact the same separation of state and civil society - or public and nonpublic - criticized by Marx or, alternatively, misses an important lesson contained in the feminist slogan, 'the personal is the political'. Moreover, according to Cohen, it would be possible for a just society to be less unequal than the standard interpretation allows if the principles of justice did not stop with the application to social institutions, but extended to the choices and actions of individuals within those societies. According to Cohen, since it fails to see that 'the personal is political', or tolerates too sharp a division between state and civil society, Rawls's liberalism settles for a just society that is less egalitarian than it strictly needs to be.

I won't take the time to develop either the further details of Cohen's criticism or Rawls's possible responses ${ }^{45}$. Rather, since my primary concern is not with the debate but with its implications for how liberal equality might best be pursued, I want to recall Rawls's wider rationale for focusing on the basic structure. Rawls's position - which I take to be fundamentally the same as Rousseau and Hegel before him - is that in considering what an ideally just society requires, we need to consider the likely effects of the operation of its primary institutions taken as a whole on the

45 For a fuller discussion, see "Ethos and Institution: On the Site of Distributive Justice", The Journal of Social Philosophy 37 (2006), pp. 182-196. 
motivations and conduct of individuals acting within those institutions (as we know them to be). Rawls's view - which thus includes empirical assumptions and not simply normative theory - is that the motivations and conduct of individuals is importantly shaped by institutions (legally coercive and non-coercive) and that a basic structure whose institutions are just is likely to shape positively the motivations of those acting within them. Though Rawls applies the principles to the basic structure taken as a whole, the principles will nonetheless, via the institutions, significantly shape the preference and behavior of actors. Cohen, it seems, rejects this claim, perhaps because he attends primarily to the selfish motivations of individuals in the competitive market alone rather than to the wider impact of just liberal-democratic institutions as a whole. An important question then is whether his skepticism is justified, especially if we consider not actually existing societies, but the operation, as in Rawls's account, of a well-ordered society based on what Rawls has called 'property-owning democracy' in contrast to welfare-state capitalism ${ }^{46}$. My own view is that it is not.

In support of my own interpretation of Rawls's position, I would argue that the focus on the basic institutions of a just society accords better with what Rawls describes as "democratic equality". In the Preface to the Revised Edition to A Theory of Justice, Rawls states that one of the prime objectives of A Theory of Justice is to integrate his conception of justice as fairness with 'democratic equality' (TJ, xii). This explains why Rawls can say, as he does in an earlier essay, that inequalities in conflict with the difference principle are unjust "in a society that already affirms the other parts of the two principles" because the difference principle "extends to the regulation of these [socioeconomic] inequalities the democratic conception already implicit in the basic structure" ${ }^{47}$. It is thus a mistake to look solely to the difference principle - and, indeed, only its application to economic institutions - for an understanding of Rawls's conception of equality. 'Democratic equality' is not secured solely through an application of the difference principle, but through the joint application of the three principles of justice - equal basic liberties - including the fair value of the political liberties -, fair equality of opportunity, and the difference principle - to the rules governing the basic institutions of society. A failure to consider this more complex conception of equality, I think, not only leads to a misreading of Rawls's aims, but, more importantly, contributes to an ultimately unattractive conception of equality that focuses on the attempt to compensate for underserved bad luck ${ }^{48}$. In Cohen's case, as we have seen, the dominant idea is to compensate for bad brute luck, or to make distributions that are 'ambition-sensitive' but endowment-insensitive' ${ }^{49}$. However, the goal of compensating for all undeserved bad luck imposes enormous informational burdens and conflicts with other equalizing

\footnotetext{
46 See, especially, Justice as Fairness: A Restatement, pp. $135 \mathrm{ff}$.

47 "Reply to Alexander and Musgrave", Collected Papers (Cambridge: Harvard University Press, 1999), p. 246.

48 For a very helpful discussion of these debates from a Rawlsian perspective, see Elizabeth Anderson, "What is the Point of Equality?" Ethics 109 (1999), 287-337.

49 See, especially, his "On the Currency of Egalitarian Justice", Ethics 99 (1989), pp. 906-944.
} 
principles: for example, the aim of democratic equality is not to insure that everyone gets what they in some sense deserve, but to secure for each person an equal status as citizen, together with the respect and entitlements such status entails ${ }^{50}$.

More specifically, and very briefly, democratic equality, as Rawls understands it, looks to the way in which the institutions of the basic structure, again taken as a whole, both reflect and enable a particular conception of citizens as free and equal moral persons. The aim is to secure, through the effects of their joint operation, the opportunity to exercise effectively what Rawls calls the two moral powers of person: the capacity to form and revise a conception of the good and the capacity for a sense of justice. Rawls also refers to these two powers as the Rational and the Reasonable, respectively, and the aim of justice as fairness can also be viewed as an attempt to express a conception of practical reason in the basic institutions of society. A society of equals, as Rawls understands it, is one based on principles that all citizens can reasonably acknowledge and that exhibits a particular form of mutual recognition or reciprocity. Thus, contrary to some interpretations, including Cohen's, the aim of justice is not to compensate for any disadvantage not due to one's own choosing. This, I have suggested, has unattractive consequences. Rather, democratic equality is achieved through the combined effect of the three principles, first, on the design of institutions of the basic structure and, secondly, through the influence that public acknowledgement of these principles and institutions has on the motivations and choices of individuals.

Though I can only briefly mention it here, I would further argue that this emphasis on 'democratic equality' also points to an important difference in the foundation of Rawls's political liberalism in comparison with more traditional liberal theory. As Rawls's puts it at one point, his theory is not 'right-based' but rather 'ideal-' or 'conception-based' 51: that is, he does not begin with a basic set of rights conceived primarily as a limit on (democratic) government. Rather, he begins with a modelconception of the citizen as a free and equal person with the two basic moral powers and attempts to show how this model-conception can be most effectively realized in a particular form of (deliberative) democracy ${ }^{52}$. This different account of the foundation of his liberal theory is, I think, also evidenced in his endorsement, in his "Reply to Habermas", of what Habermas calls the 'co-originality' or equiprimordiality of public and private autonomy ${ }^{53}$. As Habermas argues in Between Facts and Norms neither the principle of democracy (public autonomy) nor a basic scheme of liberal rights (private autonomy) should be regarded as primary. Privileging the first threatens individual civil liberties; privileging the second, however, undermines popular sovereignty by externally imposing a set of human rights. In Habermas's

50 For an excellent legal discussion of this account of citizenship equality, see Kenneth Karst, Law's Promise, Law's Expression (Yale University Press, 1993).

51 "Justice as Fairness: Political, Not Metaphysical", Philosophy and Public Affairs 14 (1985), p. 236 n.19.

52 For Rawls's remarks on deliberative democracy, see Justice as Fairness: A Restatement, p. 148 and 150; see also J. Cohen, "For a Democratic Society", in The Cambridge Companion to Rawls.

53 "Reply to Habermas", in Political Liberalism, pp. 396f. 
account, both emerge together in connection with a certain conception of (discursive) freedom and a modern conception of law. In Rawls's political liberalism, by contrast, the liberty of the ancients and the liberty of the moderns are co-original and of equal weight because "both kinds of liberty are rooted in one or both of the two moral powers" (PL, 413).

This alternative account of the roots of the two sets of liberties has wide-ranging implications for the relation between liberalism and democracy. For example, to return to the feminist slogan, 'the personal is political'. Cohen's suggestion mentioned above was that his own criticism of Rawls preserves the form, if not the substance, of this slogan in that liberalism leaves the 'personal' beyond the reach of justice. However, Rawls own remarks on feminism in Political Liberalism (and in a later essay, "The Idea of Public Reason Revisited") suggest a different lesson can be drawn. Neither the institution of the family nor, for that matter, the market, exists in a private sphere beyond the bounds of justice. Rather, "the spheres of the political and the public, of the nonpublic and the private, fall out from the content and application of the conception of justice and its principles. If the so-called private sphere is alleged to be a space exempt from justice, then there is no such thing" ${ }^{54}$. Thus, should it turn out that the gendered division of domestic labor is a primary cause or, as Susan Okin claims, 'linchpin' of women's inequality, rather than one of its primary effects, and that it cannot be effectively addressed through a guarantee of basic rights and equality of opportunity, justice itself would require seeking other remedies with respect to the design and operation of the institution of the family. As Joshua Cohen has recently expressed it, "the thesis that a decision is private, and should not therefore be regulated except for especially compelling reasons, is not best understood as a premise in normative political argument - because the decision is private, we should not regulate it - but as a conclusion of such argument" 55 . In other words, the requirements of democratic equality themselves help to define what is private and what is public, and thus what is or is not appropriately a more direct site of social justice.

The point of these two cases - political equality and egalitarianism more broadly - is that, to maintain the proper interdependence of liberty and equality, egalitarianism might best be pursued at the level of the basic structure of social institutions. The aim is not to compensate for bad brute luck, while holding individuals responsible for their choices, wherever the chips may fall. Rather, the aim is to promote institutions in which citizens are free from oppression and stand in relations of equality. However determining more precisely what the social conditions for such freedom are is itself a political - or better, democratic - project rather than something that can be specified in advance or in any great detail by theoreticians. A certain amount of bootstrapping is inevitable. However, what I think this approach does show is that the real tensions between liberty and

54 "Public Reason Revisited," in Collected Papers, p. 599.

55 Joshua Cohen, "Taking People as They Are?", Philosophy and Public Affairs 30 (2002), p. 385. 
equality, or private and public autonomy, is not a reason to dismiss more egalitarian concerns. Liberty may be in tension with equality; but it is also the case that we cannot know what liberties are worth pursuing, or what value or significance should be assigned to them, apart from a democratic process that allows for their ongoing contestation and rearticulation. Thus, if equality is in the service of liberty (as liberalism has historically claimed), it is no less true that liberty is in the service of equality, and the latter should not always be required to ride in the back seat. Finally, in contrast to Cohen's charge, it may not be that liberal egalitarians insist upon a too rigid distinction between the political and the nonpolitical (thus rendering 'individual responsibility' and/or motivation a wholly private affair), but that they have not drawn it in a way that allows for the effective access of all citizens to the social conditions of freedom ${ }^{56}$. Or, to offer a final formulation, they fail to see that the distinction between the public and the private is a distinction that must continually be renegotiated in the very exercise of citizens' public and private autonomy.

56 For a related position, see Michael Walzer, "Liberalism and the Art of Separation", which argues that the art of liberal separation leads naturally to democratic socialism [Political Theory 12 (1984), pp. 315-30]. 